\title{
Breast Cancer in Young Women - a Clinical Challenge to Be Addressed in a Multidisciplinary Setting
}

\author{
Fatima Cardoso $^{\mathrm{a}}$ Nadia Harbeck ${ }^{\mathrm{b}}$ \\ ${ }^{a}$ Head, Breast Cancer Unit and Breast Cancer, Champalimaud Cancer Center, Lisbon, Portugal \\ ${ }^{\mathrm{b} B r u s t z e n t r u m, ~ F r a u e n k l i n i k ~ u n d ~ C C C ~ L M U, ~ U n i v e r s i t a ̈ t ~ M u ̈ n c h e n, ~ G e r m a n y ~}$
}

Breast cancer in young women (below 40 years old) is becoming an important problem in the Western world (about $5.5 \%$ of breast cancers occur in women younger than the age of 40 years [1]) and it comprises a substantial proportion of breast cancer patients in developing countries. Yet, evidence on specific treatment aspects in young women is rather scarce since most clinical trials comprise women older than 40 years of age.

Recently, international efforts have started to strengthen our knowledge base for breast cancer therapy in young women. The EUSOMA (European Society of Breast Cancer Specialists) has developed specific guidelines for the management of breast cancer in this population [2]. Moreover, in November 2012, the 1st international conference on Breast Cancer in Young Women (BCY1) will be organized by the European School of Oncology in Dublin, Ireland. This conference will summarize the available evidence and will end with a 'breast cancer in young women conference statement' that will formulate research priorities and help to answer everyday management issues.

The risk of breast cancer is age-dependent, with a probability of developing breast cancer of $0.04 \%$ for average-risk women between age 30 and 39 and $>10 \%$ in those over 80 years [3]. Importantly, breast cancer in young women is associated with specific issues such as fertility preservation, pregnancy, lactation, sexuality, body image, and active professional activity, which deserve specific attention and care. In particular, fertility issues and pregnancy will become more and more important in managing breast cancer since age at first childbirth has constantly increased over the last decades [4]. There is a continuous linear effect of age as an independent adverse prognostic factor for women with a diagnosis of breast cancer [5-9], with a $4 \%$ decrease in distant recurrence and $6 \%$ in local recurrence for every additional year of age [10]. Young women also have a higher risk of contralateral breast cancer [11] and increased mortality [12]. Some preliminary studies suggest that the distribution of the different biological subtypes of breast cancer is different in young women with a higher prevalence of triple negative and HER2+ disease $[8,9]$, but a clear molecular characterization of the biology of breast cancer in young patients is still lacking.

In summary, breast cancer in young women is a clinically very challenging topic with limited evidence and a lot of complex issues impacting the management plan that need to be addressed right from the beginning, preferably in a multidisciplinary setting. Next to the aforementioned issues, such as fertility, there is an increased probability of hereditary breast cancer in a young breast cancer patient. This requires access to immediate counseling and gene testing in order to be able to adjust the treatment plan accordingly, in particular regarding surgical management and systemic therapy [13]. Last but not least, management of breast cancer in young women is confounded by psycho-social factors which arise from the very personal issues that young women need to deal with when they are confronted with a breast cancer diagnosis. For example, strong clinical evidence on therapy options may not be convincing enough for a young patient if family planning is a burning topic. Thus, particularly in young women, physicians are challenged with the need to help their patients on a very personal road to - hopefully - full recovery by utilizing the limited available evidence regarding all aspects of modern breast cancer management, such as diagnosis, surgery, radiotherapy, and systemic therapy, and finding a treatment plan that is both rationally and emotionally acceptable for the patient.

In this issue of Breast CARE, the specific problems of young women with breast cancer are discussed by renowned experts, particularly pregnancy, fertility, and sexuality, as well as specific biological characteristics of the disease in this patient population.

\section{Disclosure Statement}

The authors declare no conflicts of interests.

\section{KARGER}

Fax +497614520714

Information@Karger.de

www.karger.com
(C) 2012 S. Karger GmbH, Freiburg

$1661-3791 / 12 / 0073-0193 \$ 38.00 / 0$

Accessible online at:

www.karger.com/brc
Fatima Cardoso, MD

Head, Breast Cancer Unit and Breast Cancer Research Director

Champalimaud Cancer Center

Av. De Brasília - Doca de Pedrouços, 1400-048 Lisbon, Portugal

Tel. +351 210480 004, Fax +351213568169

fatimacardoso@fundacaochampalimaud.pt 


\section{References}

1 Samphao S, Wheeler AJ, Rafferty E, Michaelson JS, Specht MC, Gadd MA, Hughes KS, Smith BL: Diagnosis of breast cancer in women age 40 and younger: delays in diagnosis result from underuse of genetic testing and breast imaging. Am J Surg 2009;198:538-43.

2 Cardoso F, Loibl S, Pagani O, Graziottin A, Panizza P, Martincich L, Gentilini O, Peccatori F, Fourquet A, Delaloge S, Marotti L, Penault-Llorca F, Kotti- Kitromilidou AM, Rodger A, Harbeck N: The EUSOMA recommendations for the management of young women with breast cancer. Eur J Cancer 2012, in press.

3 Greif JM: Mammographic screening for breast cancer: An invited review of the benefits and costs. Breast 2010;19:268-72.

4 Harbeck N, Latta S: Chemotherapy is not the end of the road in young cancer patients who still want to become pregnant. Onkologie 2010; 33:651-2 ()
5 Adami HO, Malker B, Holmberg L, Persson I, Stone B: The relation between survival and age at diagnosis in breast cancer. N Engl J Med 1986; 315:559-63.

6 Kroman N, Jensen MB, Wohlfahrt J, Mouridsen HT, Andersen PK, Melbye M: Factors influencing the effect of age on prognosis in breast cancer: population based study. BMJ 2000;320:474-8.

7 Francis PA: Optimal adjuvant therapy for very young breast cancer patients. Breast 2011;20:297302.

8 Anders CK, Hsu DS, Broadwater G, Acharya CR, Foekens JA, Zhang Y, Wang Y, Marcom PK, Marks JR, Febbo PG, Nevins JR, Potti A, Blackwell KL: Young age at diagnosis correlates with worse prognosis and defines a subset of breast cancers with shared patterns of gene expression. J Clin Oncol 2008;26:3324-30.

9 Anders CK, Fan C, Parker JS, Carey LA, Blackwell KL, Klauber-Demore N, Perou CM: Breast carcinomas arising at a young age: unique biology or a surrogate for aggressive intrinsic subtypes? J Clin Oncol 2011;29:e18-20.

10 de la Rochefordiere A, Asselain B, Campana F, Scholl SM, Fenton J, Vilcoq JR, Durand JC, Pouillart P, Magdelenat H, Fourquet A: Age as prognostic factor in premenopausal breast carcinoma. Lancet. 1993 Apr 24;341(8852):1039-43.

11 Cluze C, Delafosse P, Seigneurin A, Colonna M. Incidence of second cancer within 5 years of diagnosis of a breast, prostate or colorectal cancer: a population-based study. Eur J Cancer Prev 2009;18:343-8.

12 Christiansen P, Al-Suliman N, Bjerre K, Møller S; Danish Breast Cancer Cooperative Group: Recurrence pattern and prognosis in low-risk breast cancer patients - data from the DBCG 89-A programme. Acta Oncol 2008;47:691-703.

13 Meindl A, Ditsch N, Kast K, Rhiem K, Schmutzler RK: Hereditary breast and ovarian cancer - new genes, new treatments, new concepts. Dtsch Arztebl Int 2011;108: 323-30. 